\title{
Impact of Microclimate Modification on Okra Cultivation: A Global Review
}

\author{
Yogendra Kumar Budania $^{1 *}$ and Harender Singh Dahiya ${ }^{2}$ \\ ${ }^{1}$ CCS Haryana Agricultural University, Hisar, Haryana-125004, India \\ ${ }^{2}$ State Agriculture Department, Government of Haryana, India \\ *Corresponding author
}

Ke y w o r d s
Okra, Microclimate,
Growth, Yield and
Crop productivity
Article Info
$\begin{aligned} & \text { Accepted: } \\ & \text { 04 September } 2018 \\ & \text { Available Online: } \\ & \text { 10 October } 2018\end{aligned}$

Keywords

Okra, Microclimate,

Growth, Yield and

Crop productivity

\section{A B S T R A C T}

Climate variability is one of the most significant factors influencing year to year crop production, even in high-yield and high technology agricultural areas. Climate influences quantity and quality of water resources, hence the productivity of agricultural regions and activities of societal concern. Okra crop productivity (such as biological and economical yield) and phenophases of the okra were affected due to the climatic factor, agronomical and management. An exhaustive review of numerous studies of past few decades took place in this paper, which systematically covers the importance, scope and apprehension regarding effect of microclimate in growth and yield of okra and it can be concluded from the results of the various studies carried out across the world that under improved management where microclimatic conditions during crop growth period are modified, there is a large potential for increasing the crop production under aberrant weather conditions for which crop weather interaction studies can be used advantageously as an aid to crop management.

\section{Introduction}

Okra [Abelmoschus esculentus (L.) Moench] is an economically important vegetable crop grown in tropical and sub-tropical regions of the world. Okra is also locally known as Lady Finger or Bhindi and is one of the major kharif and summer season cultivated vegetable crop of India as well as Haryana. It is a member of the hibiscus family, Malvaceae and has the typical floral characteristics of that family originating from Africa. It is now widely distributed in the tropics including Nigeria (National Research Council, 2006). The cultivation of okra can be done as a garden crop as well as on large commercial farm crop and nowadays okra is also cultivated under polyhouse or green house with the use of microclimatic modification strategies in all seasons. It is grown commercially in different countries like India, Turkey, Nigeria, Sudan, Iraq, Pakistan and Egypt. Okra plays a significant role in human nutrition by providing carbohydrates, protein, fat, minerals and vitamins that are generally deficient in basic foods in the diet of developing countries (IBPGR, 1991). Okra requires a long, warm and humid growing climate for better yield. It is sensitive to frost and extremely low 
temperatures. The okra plant requires warm temperatures and is unable to withstand low temperatures for long or tolerate any threat of frost. Optimum temperature is in the range of 21 to $30{ }^{\circ} \mathrm{C}$, with minimum temperature of 18 ${ }^{0} \mathrm{C}$ and maximum temperature $35{ }^{\circ} \mathrm{C}$ (Abd-ElKader et al., 2010). Adjustment of climatic factors helps in taking more than one crop at north Indian plains and almost year-round cultivation under moderate climate in south India. The suitable environment for seed production is low precipitation, low relative humidity and high light intensity with hot and dry conditions during seed ripening (Dhankhar et al., 2012). Solar radiation is a source of providing energy for living organisms and all physiological processes are dependent on photosynthetically active radiation. The optimum condition of input resources is essential for efficient utilization of photosynthetically active radiation absorption, which ultimately influences the crop yield. Temperature, humidity and radiation are major meteorological parameters, which influence all aspects and stages of crop growth. Temperature is a key component of climate, determining the seedling time and consequently the rate and duration of growth and productivity of crop (Pal et al., 2001). Agroclimatic indices i.e., growing degree days, photothermal and heliothermal units are useful for assessing the agroclimatic resources in crop planning and reflecting the impact of agro meteorological variables at different crop growth stages.

Studies on crop microclimate can provide valuable information regarding the interaction of the crop with its environment. The sowing date and planting system are two most important variable belonging changes in microclimate and consequently growth and yield. Due to its susceptibility to yellow vein mosaic virus disease area under this crop is decreasing during the rainy season. Moreover, when the crop is grown during spring-summer season its fetches better returns to the farmers due to scarcity of the other green vegetables in the market during this season. A new technique of sowing named FIRBS i.e., Furrow Irrigated Raised Bed Planting System is form of conventional tillage wherein sowing is done on the raised beds. It is one of the important components of low cost sustainable production system. The effect of microclimate on vegetables has not been much studied in India. Consequently, it is difficult to guide the farmers regarding the agrometeorology aspects of this crop and therefore, many experiments and studies on the impact of microclimate modification on okra cultivation have been conducted by various researchers all over the world. In this paper, impact of microclimate modification on okra cultivation is reviewed with the aim of helping opening up the adjustments in microclimate during crop growth and reducing the impacts such as crop failures, shortage of yields and reduction in quality under the present situation of climate change.

\section{Review of work done}

A comprehensive and critical review of past researchers provides a sound base for scientific investigations. The available pertinent literature on "Impact of microclimate modification on okra cultivation: A global review" has been reviewed under the following heads:

Crop phenology in relation to environment

Plant growth and yield in relation to environment

Characteristics of crop growth and development

Crop growth and development in relation to accumulated heat units and thermal use efficiency 
Radiation interception and radiation use efficiency

\section{Crop phenology in relation to environment}

\section{Germination and emergence}

Germination largely depends upon soil temperature and soil moisture content, while emergence depends upon seedbed conditions and the soil strength. Walter (1990) reported that the soil temperature conditions for okra seed germination is optimum in the range of about 21 to $35^{\circ} \mathrm{C}$ and the minimum is 15.5 ${ }^{\circ} \mathrm{C}$ and the maximum is $40.5{ }^{\circ} \mathrm{C}$. Lyons (1973) reported that okra injured when exposed to temperature below $12{ }^{\circ} \mathrm{C}$. Sionit et al., (1981) reported seed germination for okra (Clemson spineless) at 16/11, 20/14 and 23/17 ${ }^{\circ} \mathrm{C}$ day/night temperature, with the lowest temperature delayed the emergence. Lurline Marsh (1993) studied the effect of moisture content on the emergence and development of okra seeds and found that high moisture decreased the emergence of okra seeds. Anderson (2012) found that selection of a hybrid that germinates early under favorable temperature and then weeds would not offer competition, is the most efficient method for achieving good establishment. Singh et al., (2007) found that heat unit requirements of different genotypes of cotton increased with advancement of crop growth i.e., from germination to maturity. Yusuf et al., (2001) studied the determination of optimum temperature and moisture content for okra germination and reported that the crop germinated at $21{ }^{\circ} \mathrm{C}$ but percentage germination of the crop was high at 25, 29 and $35{ }^{\circ} \mathrm{C}$ when water applications were 100 , 80 , and $60 \%$ and declined at $40{ }^{\circ} \mathrm{C}$.

\section{Flowering}

The number of days taken from germination to flowering in okra was strongly influenced by date of sowing. Both pre and post floral growth have tremendous dependence on prevailing day and night temperature. Change in sowing date leads to change in thermal environment of crop with respect to different growth and development stages. Katung (2007) studied the influence of climatic changes on the performance of okra with two okra varieties and reported that wet season conditions were most favourable for increased leaf formation and flowering as compared with the dry season environment which resulted in less vegetative and reproductive growth. Oyolu (1977) recorded a critical day length of $12^{1 / 2}$ hours for flower initiation in okra. Welby and McGregor (1997) observed an improvement in the performance of okra when rainfall was about $750 \mathrm{~mm}$, evenly distributed and relative humidity was between 90-95\%.

However, low temperatures with the range 28.9-29.2 ${ }^{\circ} \mathrm{C}$ (maximum) and 17.9-19.8 ${ }^{\circ} \mathrm{C}$ (minimum) and short day-lengths varies from 5.2-5.7 hours resulted in a higher number of flowers (Thamburaj, 1972). Studies on the optimum weather requirement for maximum vegetative growth of okra in the tropics show that okra does best when the minimum and maximum temperatures are $18^{\circ}$ and $35{ }^{\circ} \mathrm{C}$ respectively (Ezeakunne, 1984). Sawadogo et al., (2006) observed two types flowering phases of the okra plant i.e., the period which intervenes during the accelerated growth phase of the main stem (type 1) and the one which starts once the growth of main stem begins to decline (type 2). It was also observed that water deficit during the budding phase causes earlier flowering of type 2 plants and leads to delayed flowering of the type 1 plant.

\section{Pod formation}

Okra grows and yield better during the summer, whereas the winter grow plant are 
usually retarded in growth, late in maturity and produce pods that are generally curved (Hassan, 1978).

Gunawardhana and Silva (2011) studied the impact of temperature on growth yield and related biochemical parameters of okra and reported that temperature stress has especially affected the pod formation and pod quality parameters such as fibre and pectin content.

Adekoya et al., (2014) studied the correlation and path analyses of seed yield in okra (Abelmoschus esculentus (L.) Moench) grown under different cropping seasons and reported that environmental correlation coefficients were generally low and non-significant except for number of leaves per plant, length of matured pod, width of matured pod and weight of matured pods per plant in all the seasons of study.

Ghannad et al., (2014) studied the effects of sowing date, irrigation regime and sowing method on morphological and yield related characters of okra and it was observed that moisture stress led to decrease in the average of pod formation, plant height, stem diameter, number of branches per plant, number of leaves per plant, internodes length, fruit length, number of fruits per plant and leaf area index.

Barlow et al., (2015) studied the effect of temperature extremes, frost and heat, in wheat (Triticum aestivum L.) revealed that frost caused sterility and abortion of formed grains while excessive heat caused reduction in grain number and reduced duration of the grainfilling period.

Akinyele and Osekita (2011) studied environment impact on NH47-4 variety of okra and reported that prevailing climate significantly affect the days to flowering, days to maturity, number of branches per plant, number of pods per plant, height at flowering, final height, pod length, pod width, number of seeds per pod.

Plant growth and yield in relation to environment

\section{Effect of temperature on growth and development}

Young et al., (1980) reported that the degreeday baseline is derived from a very large pool of research that studied temperature effects on different growth stages. Ashwani et al., (2012) observed that relative humidity of 7590 per cent, moderate high temperature with a range of $26-37{ }^{0} \mathrm{C}$ and intermittent rains may be responsible for rapid disease development. Olasantan and Bello (2004) reported that the meteorological data, including rainfall and temperature, vary during the early and late seasons in ways that influence growth and yield of okra crop.

Patil et al., (2009) indicated as the time required for formation of flower and bursting of bolls decreased steadily with increase in temperature. Kyriakopoulou et al., (2012) studied the effect of shading on the growth and yield of okra (Hibiscus esculentus L.) under hot, summer conditions in the Mediterranean region and reported that the number of flowers per plant was unaffected by shading in either cultivar but the total number of pods per plant decreased under $70 \%$ shading leading to a reduction in total pod weight.

In both cultivars a reduction in the number of leaves of the $70 \%$ shaded plants at the end of the experiment was due to increased abscission of the old, lower leaves. Overall, it appears that shading of okra plants during cultivation under hot Mediterranean conditions is not beneficial for okra production. 


\section{Characteristics of crop growth and development \\ Dry matter (Biomass) accumulation and its partitioning}

Ramamurthy et al., (2000) reported that the incidence of boll worm, $H$. armigera is negatively correlated with maximum and minimum temperature, wind velocity and rainfall but is positively correlated with relative humidity. Nalayini et al., (2009) observed that a widely spaced row crop, drip irrigation offers much scope in terms of enhancing cotton productivity for yield and water.

Organic mulches helped to maintain soil moisture content longer than bare soil. Mulching conserves water by reducing evaporation and mitigates negative effects of water stress on plant growth and yield under semi-arid conditions. Mulching conserves moisture contents, which in turn results in increase in the plant growth (Nasir et al., 2011). The greater number of leaves per chilli plant was recorded in rice straw mulch followed by wheat straw mulch and sugarcane bagasse mulch. Control plants recorded the lowest number of leaves per plant, (Iftikhar et al., 2011).

Thakur et al., (2000) reported that Lantana leaves and grass mulches maintained higher number of branches as compared to unmulched treatments. Gandhi and Bains (2006) reported of higher number of tomato plants branches under straw mulch as compared to no mulch. Application of glyricidia mulch recorded higher dry matter production as compared to no mulch and further crop residue mulch (Venkanna, 2008). Norman et al., (2011) also reported of maximum dry upper plant biomass of okra plants by dry grass mulch compared to the control plants.
Growth, yield and yield attributes

\section{Date of sowing}

Date of sowing is an important factor influencing phenology, yield potential and water use efficiency of the crop. Optimum date of sowing provides proper environmental condition for germination, growth, development and yield and optimum utilization of available soil moisture by the roots. Lu and Zhou (1991) planted soybean at four different dates to have different environmental conditions and observed that the earliest sowing gave plants enough time to develop pods and seeds to get fully matured before the high temperatures and drought become limiting factor and seed cotton yield. Lee et al., (1988) observed that seed weight was reduced due to later sowings, which was positively correlated with days to flowering, stem length and number of nodes in main stem at maturity. Dilruba et al., (2009) conducted a field experiment to evaluate the response of sowing time on growth and yield of okra. Three sowing times were March 22, April 06 and April 21. Results showed that both the fruit number and fruit yield significantly affected by sowing time. In case of sowing times, 06 April sowing produced the higher yield (13.88 $\left.\mathrm{t} \mathrm{ha}^{-1}\right)$ and 22 March sowing produced the lowest yield (10.22 $\mathrm{t} \mathrm{ha}^{-}$ $\left.{ }^{1}\right)$. Elhag and Ahmed (2014) studied the effect of three sowing dates, 1 st and $20^{\text {th }}$ of July and $10^{\text {th }}$ of August on seed yield of two okra cultivars (Khartoumia and Wad Gammer) and the results showed that late sowing $\left(20^{\text {th }}\right.$ of July and $10^{\text {th }}$ of August) had significant negative effects on both vegetative growth and yield of both cultivars. The best vegetative growth and yield were obtained at $1^{\text {st }}$ of July. Almost similar negative response of both cultivars to late sowing was noticed. It could be concluded that both okra growth and seed yield were significantly negative affected by late sowing (last week of July or later). 
Islam et al., (2000) reported high pod and seed yield from July sowings compared to late August and October sowings. Higher seed yield of a number of okra cultivars were obtained from June sowings compared to late July sowings (Shujat et al., 2006). Soomro et al., (2000) while studying on the optimum time of sowing concluded that crop sown from $5^{\text {th }}$ to $20^{\text {th }}$ may gave highest yield as compared to early or late sown under Sakrand conditions.

\section{Varieties}

Yadav and Dhankar (2001) reported that crop sown at $45 \times 30 \mathrm{~cm}$ recorded the highest test weight $(57.4 \mathrm{~g})$, standard germination $(81.35 \%)$, seedling vigour (25) and vigour index (1970). However, sowing on $13^{\text {th }}$ June at a spacing of $45 \times 30 \mathrm{~cm}$ gave highest seed yield and quality. Gowda et al., (2001) compared the three okra varieties with nutrients and found that the Varsha uphar is the best for higher nutrient accumulation and uptake of nutrient. Singh et al., (2015) studied over 36 cultivars of okra (Abelmoschus esculentus L. (Moench).

All the cultivars showed similar expression for each characters over the four consecutive year (kharif, 2010, 2011, 2012 and 2013) depicting the stability of cultivars. Cultivars Pusa A-4, Kashi Leela and Punjab Padmini were early in flowering (45 days) in flowering. Length of fruit $(\mathrm{cm})$ at marketable stage (four days after anthesis) varied from small to long in the cultivars studied. Only one cultivar SB-2 have small fruit length while, Susthira, Varsha Uphar, Kashi Vibhuti, $\mathrm{D}_{1}-87-5$ and No.136 showed long fruit length and rest cultivars showed medium fruit length. Only three cultivars, viz., Susthira, No. 315, and Kashi Vibhuti exhibited short plant height $(120 \mathrm{~cm})$ plant height group. Omotoso and Johnson (2015) studied the growth and yield of two varieties of okra (Abelmoschus esculentus (L). Moench). Two varieties of okra (Abelmoschus esculentus (L). Moench) were TAE-38 and Clemson spineless (47-4) assessed in a pot experiment and plant height, number of leaves, leaf area, number of pods, length of pods and fresh weight of pods were measured. There was significant effect between the two varieties. Improved variety (47-4) gave a significant increase in height over TAE-38 variety. There was varietal difference in term of pod weight and yield, improved variety 47-4 gave significant increase over TAE-38. The increase was such that 47-4 gave $23 \%$ increase over TAE-38 variety. Ram et al., (2013) studied the effect of cultivars on growth and yield of okra [Abelmoschus esculentus (L.) Moench]. The data revealed significant differences among the varieties. Among four varieties viz., V.R.O.-6, Parbhani Kranti, Arka Anamika and Arka Abhay, variety V.R.O.-6 proved its dominance over other varieties regarding to both attributes (yield and growth)

\section{Crop growth and development in relation to accumulated heat units and thermal use efficiency}

Radiant energy plays an important role not only in plant growth and development processes through photosynthesis, and the thermal effects but also determines the climate near the ground depending upon the surface. The net radiation, which is balance of net short wave and net long wave radiation, is the fundamental source of energy, which is responsible for most of the physical processes taking place in the environment, within the crop canopy and surrounding the crop cultivated area (Kaur et al., 2004). Radiation has two essential functions, providing light for direct growth and development and providing heat (thermal condition) for indirect physiological actions. The greatest annual input to solar radiation occurs in sub-tropical regions in latitudes between 20 to $30{ }^{\circ} \mathrm{C} \mathrm{NS}$, 
in climates with little cloud cover and correspondingly low rainfall (Chai et al., 1990).

\section{Heat units and phenology}

Heat stress causes multifarious, and often adverse, alterations in plant growth, development, physiological processes, and yield. Heat stress affects all aspects of plant processes like germination, growth, development, reproduction and yield (Hasanuzzaman et al., 2012). Reduced germination percentage, plant emergence, abnormal seedlings, poor seedling vigor, reduced radicle and plumule growth of geminated seedlings are major impacts caused by heat stress documented in various cultivated plant species (Kumar et al., 2011). Damages in pod quality parameters such as fibre content and break down of the Calcium pectate were found in okra (Abelmoschus esculentus) at HT stress (Edreira et al., 2012). Singh et al., (2007) found that heat unit requirements of different genotypes of cotton increased with advancement of crop. Peng et al., (2014) reported that a heat unit is a measure of the amount of heat energy a plant accumulates each day during the growing season and has been used to describe the development of crops.

\section{Heat units and biomass accumulation}

Gonias et al., (2012) reported that crop growth and yield varies among locations due to differences in environmental parameters, such as temperature, relative humidity, solar radiation and vapor pressure deficit. Previous research has shown that increasing vapor pressure deficit has a negative effect on radiation use efficiency of many crops. In this study, the radiation use efficiency of cotton (Gossypium hirsutumbL.) grown in two contrasting production environments, Arkansas and California, was evaluated for two years, in 2006 and 2007. Temperature, relative humidity, vapor pressure deficit and photosynthetically active radiation were recorded at both locations. Although the crop in California accumulated more dry matter during the period of the study, the radiation use efficiency was found to be lower compared to Arkansas. Radiation use efficiency for the Arkansas and California locations was estimated at 2.060 and $1.518 \mathrm{~g}$ $\mathrm{MJ}^{-1}$ of intercepted photosynthetically active radiation, respectively. The higher productivity observed in California can be attributed to larger amounts of incident and intercepted radiation in this location. Radiation use efficiency of cotton was estimated to decrease with increasing vapor pressure deficit by a slope of $-0.47 \mathrm{~g} \cdot \mathrm{MJ}^{-}$ ${ }^{1} \cdot \mathrm{kPa}^{-1}$. Sharaiha and Hadidi (2008) studied the effect of air and soil temperature, light intensity, soil moisture storage, evapotranspiration, and water use efficiency on the yield of okra and reported that okra yield increases significantly and the increases in okra yields were associated with increases in air heat unit (by 29 and 16.3), soil heat unit (by 53.7 and 55.1), light intensity (by 305 and $150 \mu \mathrm{mol} \mathrm{m} \mathrm{m}^{-2} \mathrm{~s}^{-1}$ ) and WUE (by 0.261 and 0.242 ton $/ \mathrm{ha} / \mathrm{cm})$.

\section{Radiation interception and radiation use efficiency}

\section{Radiation interception and biomass production}

Singh and Singh (2000) indicated that, the crop plants should cover the soil as early as possible to intercept maximum sunlight to produce higher dry matter as the intercepted solar radiation and dry matter production are directly related. Closely spaced and quick growing crops as soya bean, which can intercept more light within a short period of time, gives higher yield compared to wider spaced crops. The transformation of solar 
energy into biomass is an economical but inefficient process as close to $2 \%$ of the incoming solar energy captured by the crop within the photosynthetically active spectrum of solar radiation is transformed into biomass (Vargas et al., 2002). The efficiency of a crop to convert intercepted solar radiation into biomass is considered to be a key determinant of crop yield in many crops (Sinclair and Muchow 1999). Biomass production of the crop, and yield, is often linearly related to the photosynthetically active radiation absorbed or intercepted by a crop and this relationship or radiation use efficiency is a useful method to quantify canopy photosynthesis (Monteith, 1977). The RUE of cotton is reported to be within the range of $0.71-2.71 \mathrm{~g} \mathrm{MJ}^{-1}$ (Bange and Milroy, 2004).

\section{Radiation use efficiency}

A major determinant of crop growth and yield is radiation interception (Monteith, 1977). Production of assimilates by the leaves is the primary determinant of yield. Adequate carbohydrate production by the leaves is essential to support both vegetative and reproductive growth. While the pattern of light penetration and light interception by the canopy is important in most crops, it is particularly important in cotton because the earliest fruit are produced on lower branches of the plant in the bottom half of the canopy (Constable, 1986). The ability of the crop to intercept radiation is largely determined by leaf area (Hay and Walker, 1989). LAI values greater than 3 have been reported to intercept the maximum amount of radiation and maximized crop growth rate (Constable and Gleeson, 1977). Evangelos et al., (2012) studied the radiation use efficiency of cotton in two different environmental conditions and found that, higher productivity was observed to amount of incident and intercepted radiation and decrease in radiation use efficiency with increasing vapour pressure deficit by a slope of $-0.47 \mathrm{~g} \mathrm{MJ}^{-1} \mathrm{kPa}^{-1}$. Dehariya et al., (2012) examined the photosynthesis and yield of cotton and found the fluorescence measurements enhanced Fv/Fm (Fluorescence visible/Fluorescence measured) ratio and reduction in capacity after exclusion of solar UV and also exclusion enhanced stomatal conductance and intercellular $\mathrm{CO}_{2}$ concentration and reduced the stomatal resistance and concluded that exclusion of solar UV is beneficial for enhancing the yield of cotton plants.

\section{Effect of different growing environments on okra yield}

Environmental factors that mean, any given crop variety has its own potential requirements of and/or selective response to the factors of its environment like rainfall/soil moisture supply, day, night temperature, BSS, or mean air temperature, soil warmth, duration of darkness, light intensity, etc. these response and requirements which determine the growth and development of a plant in the given environment at given location (Went, 1957). Unfavorable climatic conditions such as drought, edaphic factors, excess or low light intensity can damage the quality and reduce the yield (Agbogidi and Nweke, 2005). Radiation levels can be influenced by climatic conditions. Cloudy conditions during flowering and fruit development can cause significant reductions in yield and fibre quality (Zhao and Oosterhuis, 2000). It was reported that plants grown under high light intensity are capable of stronger photosynthesis than those grown under weaker light (Knorr and Vegtmann, 1983). Leafs formed in shade are also thinner than those formed under sun or high light intensity. Meanwhile, different plants have optimum light requirements for optimum performance and both low, and high/excessive light intensities are injurious to plant growth. When in excess, light inhibits stem growth due to its 
effect on gibberellins while deficit in light intensities tends to reduce plant growth, development and yield (Vergara, 1978). This is because low amount of solar energy, reduce the rate of photosynthesis and below a certain/minimum light intensity, the plant growth will fall below what is called the 'compensation point' (Edmond et al., 1978). Optimum light requirement by okra crop must therefore be determined. However, with the optimum light intensity, crop performance can also be limited by inadequate availability of essential nutrients in the soil (Akande et al., 2004). Fertilizer is an important input contributing to crop production because it increases productivity and improves yield quality and quantity (Adeniyan and Ojeniyi, 2003).

Though the change in climate is a continuous process, it has become recognizable when it has started significant and lasting effect on crop production. The reasons for climate change cannot be underlined exactly, however, as per the available literature; growing industrialization and mechanization might be responsible to some extent. Therefore, it is clear from the results of previous studies climate change is going to have greater impact on global food security and therefore, more and more research is needed on crop weather interaction studies which can be used advantageously as an aid to crop management and for developing improved management practices as they have the large potential for increasing the crop production under aberrant weather conditions.

\section{References}

Abd-El-Kader, A. A., Shaaban, S. M., AbdEl-Fattah, M. S. 2010. Effect of irrigation levels and organic compost on okra plants (Abelmoschus esculentus L.) grown in sandy calcareous soil. Agric. Bio. J. N. Am. 1(3): 225-231.
Adekoya, M. A., Ariyo, O. J., Kehinde, O. B. and Adegbite, A. E. 2014. Correlation and path analyses of seed yield in okra (Abelmoschus esculentus (L.) Moench) grown under different cropping seasons. Pertanika J. Trop. Agric. Sci. 37 (1): 39 $-49$.

Adeniyan, O. N. and Ojeniyi, S. O. 2003Comparative effectiveness of different levels of poultry manure with NPK fertilizer on residual soil fertility, nutrient uptake and yield of maize. Moor J. Agril. Res. 4(2):191-197.

Agbogidi, O. M. and Nweke, F. U. 2005. Effects of crude oil polluted soil on the performance of okra (Abelmoschus esculentus) Moench in Delta State. African J. Natu. Sci. 8: 31-35.

Akande, M. O., Oluwatoyinbo, F. I., Adediran, J. A., Buari, K. W. and Yusuf, I. O. 2004. Soil amendments affect the release of $\mathrm{P}$ from rock phosphate and the development and yield of okra. J. Veg. Crop Prod. 9(2): 3-9.

Akinyele, B. O. and Osekita, O. S. 2011. Genotype and environment interaction in NH47-4 variety of okra Abelmoschus esculentus (Linn.) Moench. Internl. J. Genet. Mole. Bio. 3(4): 55-59.

Anderson, J. 2012. Advances in Plant Dormancy. USDA-Agricultural Research Service Fargo, North Dakota, USA.

Ashwani, Chohan, P. K., Singh, R., Dang, J. K. and Chauhan, M. S. 2012. Impact of weather parameters on the appearance and development of bacterial blight of cotton in Haryana. J. Cotton Res. Dev. 26(2): 248-250.

Bange, M. P. and Milroy, S. P. 2004. Growth and dry matter partitioning of diverse cotton genotypes. Field Crops Res. 87(1): 73-87. 
Barlow, K. M., Christy, B. P., Leary, G. J., Riffkin, P. A. and Nuttall, J. G. 2015. Simulating the impact of extreme heat and frost events on wheat crop production: a review. Field Crops Res. 171: 109-119.

Chai, Q. H., Liu, D. J. and Chen, S. H. 1990. Effect of several meteorological factors on the yield of spring cotton in Fujian. J. Agricoll. 19: 163-166.

Constable, T. 1986. Leaf nitrogen, photosynthesis, and crop radiation use efficiency: A review. Crop Sci. 29: 9098.

Constable, W. D. and Gleeson, T. J. 1977. Radiation use efficiency among cotton cultivars. Agron. J. 83: 655-658.

Dehariya, P., Katariia, S., Guruprasad, K. N. and Pandey, G. P. 2012. Photosynthesis and yield in cotton (Gossypium hirsutum L.) Var. Vikram after exclusion of ambient solar UV-B/A. Acta Physio. Plant. 34: 1133-1144.

Dhankhar, S. K., Deswal, D. P. and Singh, S. 2012. Impact of weather variables on yield and yield attributes of okra under different growing environments. $J$. Agromet. 14(1): 54-56.

Dilruba, S., Hasanuzzaman, M., Karim, R. and Nahar. K. 2009. Yield Response of Okra to different sowing time and application of growth hormones. $J$. Hort. Sci. Orname. Plants. 1(1): 10-14.

Edmond, J. B., Senn, T. L., Andrews, F. S. and Halfacre, R. G. 1978. Fundamentals of Horticulture. 4th Edition. McGrawHill Inc pp: 109-130.

Edreira, J. I. R. and Otegui, M. E. 2012. Heat stress in temperate and tropical maize hybrids: Differences in crop growth, biomass partitioning and reserves use. Field Crops Res. 130: 87-98.

Elhag, A. Z. and Ahmed, A. A. 2014. Effect of cultivar and sowing date on Okra (Abelmoschus Esculentus L. Moench.) seed yield. Uni. J. Appl. Sci. 2(3): 6467.

Evangelos, D. G., Derrick, M. O., Androniki, C. B. and Bruce, A. R. 2012. Radiation use efficiency of cotton in contrasting environments. American J. Plant Sci. 3: 649-654.

Ezeakunne, C. O. 1984. Large scale fruit and vegetable production in Nigeria. Short Communication. Department of Agronomy, Ahmadu Bello University, Zaria, 8pp.

Gandhi, N. and Bains, G. S. 2006. Effect of mulching and date of transplanting on yield contributing characters of tomato. J. Res. Punjab Agril. 43(1): 6-9.

Ghannad, M., Madani, H. and Darvishi, H. H. 2014. Responses of Okra crop to sowing time, irrigation interval and sowing methods in Shahrood Region. Int. J. Agril. Crop Sci. 10: 676-682.

Gonias, E. D., Derrick, M. O., Androniki, C. B. and Roberts, B. A. 2012. Radiation use efficiency of cotton in contrasting environments. American J. of Plant Sci. 3: 649-654.

Gowda, K. P., Mohanta, B. K. and Bharma, R. J. 2001. Effect of nitrogen, spacing and green fruit pickings on the seed production of okra (Abelmoschus esculentus L. Moench). Veg. Sci. 15(1): 8-14.

Gunawardhana, M. D. M. and De Silva, C. S. 2011. Impact of temperature and water stress on growth yield and related biochemical parameters of Okra. Trop. Agril. Res. 23(1): 77-83.

Hasanuzzaman, M., Hossain, M. A., De Silva, J. A. T. and Fujita, M. 2012. Plant responses and tolerance to abiotic oxidative stress: Antioxidant defenses is a key factor. In: Bandi V., Shanker A. K., Shanker C., Mandapaka M., editors. Crop Stress and Its Management: Perspectives and Strategies. Springer; Berlin, Germany: pp. 261-316. 
Hassan, G. M. 1978. Effect of bed orientation on tropical crops during the winter in the Sudan. Acta Horti. 84: 91-94.

Hay, T. and Walker, L. 1989. Morphological analysis of plant density effects on early leaf area growth in maize. Netherlands J. Agril. Sci. 48: 199-212.

IBPGR 1991. Report of International workshop on Okra genetic resources, held at The National Bureau for Plant Genetic Resources (NBPGER), New Delhi, India, 8-12 Oct, 1990.

Iftikhar, A., Zahoor H., Shuaib, R., Noor-UnNisa, M. and Summar, A. N. 2011. Response of vegetative and IBPGR reproductive components of Chilli to inorganic and organic mulches. Pakistan J. Agril. Sci. 48(1): 19-24.

Islam, M. S., Rahman, M. M. and Chowdhury, A. K. 2000. Off season performance of okra for edible pod and seed production. Thailand J. Agril. Sci. 33(3-4): 107-113.

Katung, M. D. 2007. Productivity of okra varieties as influenced by seasonal changes in northern Nigeria. Not. Bot. Hort. Agrobot. Cluj. 35(1): 65-71.

Kaur, P., Dhaliwal, L. K. and Hundal, S. S. 2004. Agro-meteorological indices for predicting growth and yield of wheat (Triticum aestivum) under Punjab conditions. J. Agromet. 6: 16-20.

Knorr, D. and Vogtmann, H. (1983). Quality and quantity determination of ecologically grown foods. In: Sustainable Food Systems. Knorr D (Ed). AVI Publishing Co, Westport, Connecticut pp 352-381.

Kumar, S., Kaur, R., Kaur, N., Bhandhari, K., Kaushal, N., Gupta, K., Bains, T. S., Nayyar, H. 2011. Heat stress induced inhibition in growth and chlorosis in mungbean (Phaseolus aureus Roxb.) is partly mitigated by ascorbic acid application and is related to reduction in oxidative stress. Acta Physiol. Plant. 33: 2091-2101.

Kyriakopoulou, O. G., Karapanos, I. C., Tsikritsakis, G., Tsermoulas, S., Alexopoulos, A. A. and Passam, H. C. 2012. Effect of Shading on the development and yield of two okra (Hibiscus Esculentus L.) cultivars grown under high temperatures. XXVIII International Horticultural Congress on Science and Horticulture, 936.18.

Lee, K. H., Cho, C. Y., Yoon, S. T. and Parsk, S. K. 1988. The effect of nitrogen fertilizer, planting density and sowing date on the yield of okra. Korean J. of Crop Sci. 35(8): 197-183.

Lu, D. T. and Zhou, Y. E. 1991. The effect of soyabean genotype and sowing date on the yield in Fuzhou area. Soyabean Sci. 10: 231-233.

Lurline Marsh 1993. Moisture affects cowpea and okra seed emergence and growth at low temperatures. Hort. Sci. 28(8): 774777.

Lyons, J. M. 1973. Chilling injury in plants. Ann. Rev. Plant Physiol. 24: 445-466.

Monteith, J. L. 1977. Climate and the efficiency of crop production in Britain. Biol. Sci. 281(980): 937-947.

Nalayini, $\quad$ P., Anandham, R., Sankaranarayanan, K. and Rajendran, T. P. 2009. Polyethylene mulching for enhancing crop productivity and water use efficiency in cotton (Gossypium hirsutum) and maize (Zea mays) cropping system. Ind. J. Agron. 54(4): 409-419.

Nasir, M., Moazzam, A., Shahbaz, A. and Zakaullah. 2011. Effect of mulching on vegetables production in tunnel farming. Mycopath. 9(1): 21-24.

National Research Council. 2006. Okra, lost crop of Africa: Vegetables. 2: 201-204.

Norman, J. C., Opata, J. and Ofori, E. 2011. Growth and yield of okra and hot 
pepper as affected by mulching. Ghana J. of Horticulture. 9: 35-42.

Olasantan, F. O. and Bello, N. J. 2004. Optimum sowing dates for okra (Abelmoschus esculentus) in monoculture and mixture with cassava (Manihot esculenta) during the rainy season in the south-west of Nigeria. $J$. Agril Sci. 142: 49-58.

Omotoso, S. O., Johnson, O. Y. 2015. Growth and yield of two varieties of Okra (Abelmoschus esculentus (L). Moench) as affected by potassium fertilizer sources. J. Bio. Agril. Healthcare. 5(8): 98-104.

Oyolu, C. 1977. Variability in photoperiodic response of okra (Hibiscus esculentus L.). Acta Hort. 52: 207-15.

Pal, S. K., Verma, U. N., Singh, M. K., Upsani, R. P. and Thakur, R. 2001. Growth and yield of late sown wheat under different irrigation schedules. Indian J. Agric. Sci. 71(10): 664-667.

Patil, D. V., Deosarkar, D. B. and Patil, S. G. 2009. Study of $B t$ and non- $B t$ cotton hybrids for yield and quality characters under normal and delay-sown condition. J. Cotton Res. Dev. 23(2): 199-203.

Peng, H., Yuee, L., Ruizhi, X., Ming, B., Daling, M., Shaokun L., Xurong, M. 2014. Temporal and spatial variation in accumulated temperature requirements of maize. Field Crops Res. 158: 55-64.

Ram, H., Khan, M. M. and Singh, P. K. 2013. Effect of spacing and cultivars on growth and yield of okra [Abelmoschus esculentus (L.) Moench]. Asian J. Hort. 8(2): 507-511.

Ramamurthy, M., Rajaram, V., Rajenderan, M. and Krishnadoss, D. 2000. Impact of weather parameters on cotton pests. $J$. Cotton Res. Dev. 14: 193-195.

Sawadogo, W., Kehinde, O. B. and Yayock, J. Y. 2006. Emergence and seedling growth of okra genotypes at low tempetaures. Hortscience. 27:1310-12.
Sharaiha, R. K. and Hadidi, N. A. 2008. Environmental impact on yield of pea and okra grown under intercropping. Lucrari Ştiinţifice. 50: 313-323.

Shujat, H., Muhammed, S., Noor-ul, A. and Zafar, J. 2006. Response of okra (Abelomischus esculentus L. Moench) cultivars to different sowing times. Agric. J. of Biological Sci. 1(1): 55-57.

Sinclair' T. R. and Muchow, R. C. 1999. Radiation Use Efficiency. Adva. Agron. 65: 215-265.

Singh, B., Chaubey, T., Upadhyay, D. K., Jha, A., Pandey, S. D. and Sanwal, S. K. 2015. Varietal characterization of okra (Abelmoschus esculentus) based on morphological descriptions. Indian J.of Agri. Sci. 85(9): 1192-1200.

Singh, N. P. and Singh, R. A. 2000. Scientific Crop Production. Dehli-28.1 st ed., India. pp. 170.

Singh, S., Butter, G. S and Singh, S. 2007. Heat use efficiency of $\mathrm{Bt}$ cotton cultivars in the semi- arid region of Punjab. J. Agromet. 9(1): 122-124.

Sionit, N., Strain, B. R. and Beckford, H. A. 1981. Environmental controls on the growth and yield of okra. Effects of temperature and of $\mathrm{CO}_{2}$ enrichment at cool temperatures. Crop Sci. 21: 885888.

Soomro, A. R, Channa, M. H., Channa, A. A., Kalwar, G. H., Dayo, G. N. and Memon, A. H. 2000. The effect of different sowing dates on the yield of newly developed strain under climatic conditions of Ghotki, Sindh. The Pakistan Cot. 44(1\&2): 25-29.

Thakur, P. S. Thakur, A., Kanaujia, S. P. and Thakur, A. 2000. Reversal of water stress effects. Mulching impact on the performance of Capsicum annuum under water deficit. Ind. J. Horti. 57: 250-254.

Thamburaj, S. 1972. Response of okra (Abelmoschus esculentus (L.) Moench) 
to thermo and photoperiods. Madras Agric. J. 59(6): 339-346.

Vargas, L. A., Andersen, M. N., Jensen, C. R., Jorgensen, U. 2002. Estimation of leaf area index, light interception and biomass accumulation of Miscanthus sinensis 'Goliath' from radiation measurements. Biomass and Bio. 22: 114.

Venkanna, Y. 2008. Effect of mulches, organics and organic solutions on growth, yield and quality of chilli (Capsicum annuum 1.) Cv. Byadagi dabbi in northern transition zone of Karnataka. Thesis, University of Agricultural Science. Dharwad, Karnataka, India.

Vergara, B. S. 1978. Crop response to light variations. In: Gupta US, Ed Crop Physiology. New Delhi, Oxford \& IB Publishing Co. pp 137- 156.

Walter, E. S. 1990. Vegetable growing Handbook Organic and Traditional methods. Van Nostrand Reinhold. p: 95.

Welby, E. M. and McGregor, B. 1997. Agricultural export transportation hand book. USDA Agricultural Handbook,
United States Department of Agriculture (URL: http:/www.ams Usda.gov. /tmd/export/index.htm. p 10.

Went, J. P. 1957. Effects of light intensity during growth on leaf anatomy and subsequent light saturated photosynthesis among contrasting Lolium genotypes. New Phytologist. 68(4): 1225-1135.

Yadav, J. R. and Dhankar, S. K. 2001. Determining selection components in okra [Abelmoschus esculentus (L) Moench]. Prog. Agric. 2(2): 185-189.

Young, E. F., Taylor, R. M. and Peterson, H. D. 1980. Day-degree units and time in relationship to vegetative development and fruiting for three cultivars of cotton. Agron. J. 20: 270-274.

Yusuf, K. O., Iyanda, M. O. and Olayiwola, T. E. 2001. Determination of optimum temperature and moisture content for crop germination. J. Agril. Res. Dev. 3: 39-49.

Zhao, D. and Oosterhuis, D. M. 2003. Cotton growth and physiological responses to boron deficiency. J. Plant Nutri. 26: 855-867.

\section{How to cite this article:}

Yogendra Kumar Budania and Harender Singh Dahiya. 2018. Impact of Microclimate Modification on Okra Cultivation: A Global Review. Int.J.Curr.Microbiol.App.Sci. 7(10): 426438. doi: https://doi.org/10.20546/ijcmas.2018.710.045 